\title{
ECONOMICAL PLACEMENT OF SHEAR WALLS IN A MOMENT RESISTING FRAME FOR EARTHQUAKE PROTECTION
}

\author{
Raghav Singh Shekhawat ${ }^{1}$, Anshul Sud ${ }^{2}$, Poonam Dhiman ${ }^{3}$ \\ ${ }^{1}$ Department of Civil Engineering, Jaypee University Of Information Technology, Waknaghat, India \\ ${ }^{2}$ Department of Civil Engineering, Jaypee University Of Information Technology, Waknaghat, India \\ ${ }^{3}$ Department of Civil Engineering, Jaypee University Of Information Technology, Waknaghat, India
}

\begin{abstract}
Shear walls are one of the most basic lateral load resisting elements in an earthquake resistant building. To avoid torsion in buildings, shear walls must be placed symmetrically in plan. In this paper, a five-storey RC building located in seismic zone-V is considered with four shear walls. Five different configurations of shear walls viz. bare frame, shear wall symmetrically placed at exterior bays (centrally), at core and adjacently placed in exterior of the building, are considered. These frames are analysed for seismic forces to assess performance in terms of base shear, storey drift, member forces and joint displacements. The frame with shear walls at core and centrally placed at exterior bays showed significant reduction of order $29 \%$ to $83 \%$ in lateral displacement. The reduction in bending moments is approximately $70 \%$ to $85 \%$ for interior and perimeter columns respectively. Shear and axial forces in columns have reduced by $86 \%$ and $45 \%$ respectively. Then in order to make our building economically feasible we curtailed the top and second topmost storeys of our building and hence accordingly drew dawn the results in this paper.
\end{abstract}

Keywords - Seismic resistance, shear wall, base shear, storey drift, curtailment

\section{INTRODUCTION}

Reinforced concrete buildings often have vertical plate-like $\mathrm{RC}$ walls, called shear walls. Shear walls are like verticallyoriented wide beams that carry earthquake or wind loads and transfer them downwards to the foundation. Their thickness can be as low as $150 \mathrm{~mm}$ or as high as $400 \mathrm{~mm}$ in high rise buildings. Shear walls are usually provided along both length and width of buildings. Most RC buildings with shear walls also have columns. These columns primarily carry gravity loads and shear walls are designed to carry lateral loads. Shear walls provide large strength and stiffness to buildings in the direction of their orientation, which significantly reduces lateral sway of the building and thereby reduces damage to structure and its contents. In this paper, five frames with different placement of shear walls are analysed for their performance in terms of base shear, storey drift, member forces and joint displacements and after figuring out the most optimum frame case make it economically feasible by cutailing its top and second highest storey simultaneously asessing the affect it does on maximum bending moment, shear force, axial force and storey drift.

\section{PROBLEM FORMULATION}

A Five-storey RC office building is assumed to be located in seismic zone V on medium soil (as per IS 1893:2002). It is designed as anordinary moment-resisting frame. Column sections of size $350 \mathrm{~mm} \times 500 \mathrm{~mm}$, beam sections of size $500 \mathrm{~mm} \times 500 \mathrm{~mm}, 125 \mathrm{~mm}$ thick RCC slab on all floors and shear wall having $300 \mathrm{~mm}$ thickness are taken for proposed work.In $\mathrm{x}$-direction (the longer direction in plan) there are 5 bays, each of $4 \mathrm{~m}$ width and in $\mathrm{z}$-direction (the shorter direction in plan) there are 3 bays, each of $5 \mathrm{~m}$ width. The column height throughout the structure is $3.5 \mathrm{~m}$. Five frames with different shear wall configurations viz. bare frame (frame 1), shear wall symmetrically placed at exterior bays centrally (frame 3), at core (frame 2) and adjacently placed in exterior of the building (frame 4 and 5)as shown in Fig.1 are taken for the study. These frames are subjected todead load, imposed load of $4 \mathrm{kN} / \mathrm{m}^{2}$ on all floors, imposed load of $1.5 \mathrm{kN} / \mathrm{m}^{2}$ on roof (as per IS 875-part 2) and earthquake loads as per IS 1893:2002.

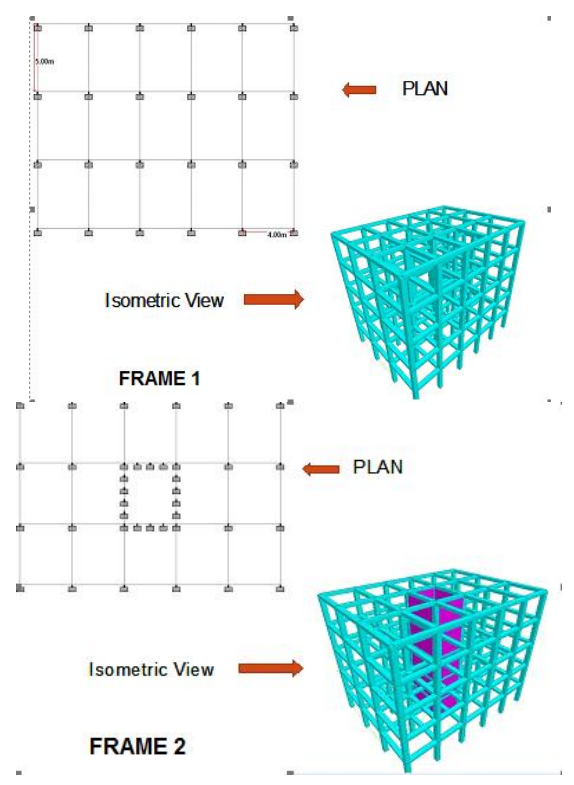




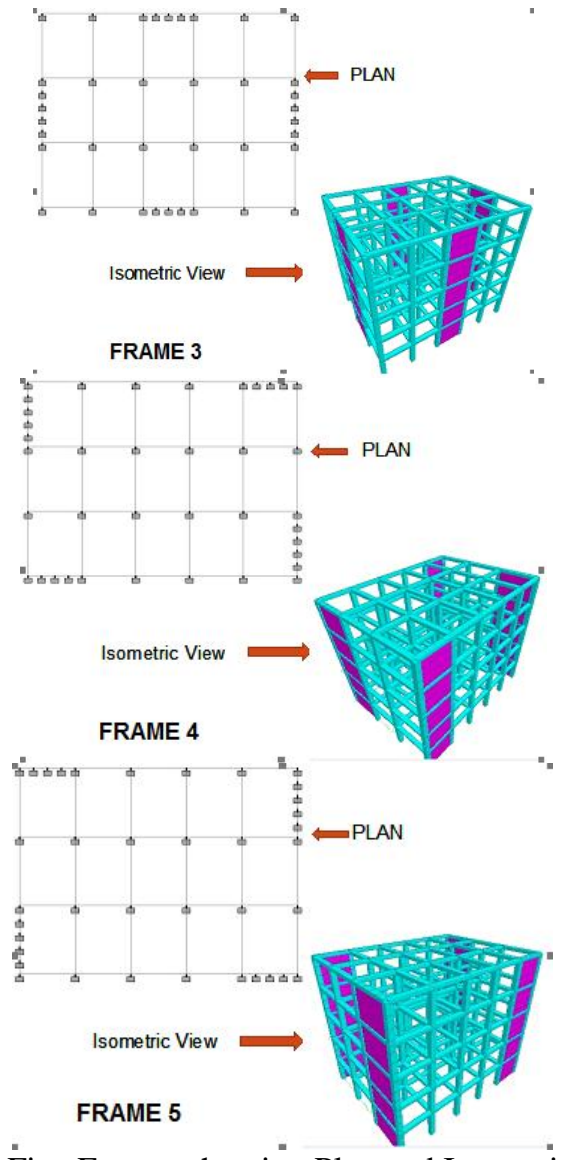

Fig. 1: Five Frames showing Plan and Isometric View

These frames are analysed for load combinations suggested by IS 1893 , i.e,

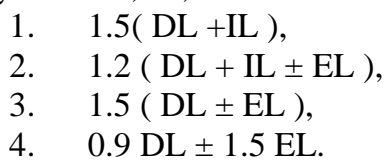

For the calculation of base shear, the zone factor ' $\mathrm{Z}$ ' is taken as 0.36 for seismic zone V, Importance Factor 'I' equal to 1 , Response reduction factor ' $R$ ' as 3 as it is an Ordinary RC moment resisting frame and fundamental natural period of vibration (T) is calculated as 0.352 seconds for $\mathrm{x}$-direction and 0.406 seconds for z-direction (as per IS:1893-2002).

\section{ANALYSIS OF RESULTS}

\subsection{Figuring out the Most Suitable Frame}

\subsubsection{Bending Moment in Columns}

After carrying out analysis, bending moments $(\mathrm{kNm})$ in bottom storey columns for all frames are taken from output file andare shown in Fig. 2. The maximum value of bending moment both in the case of interior and perimeter columns for ground storey columns are seen in the case of Frame1 which is the frame with no shear wall which comes out to be 233 and $230 \mathrm{kNm}$ respectively whereas the minimum value for both are seen in the case of Frame-2 where shear walls are placed at the inner core of the building symmetrically which comes out to be 30 and $51.7 \mathrm{kNm}$. From Fig. 2, it can be concluded that frame-2 have significant reduction in bending moment of ground storey columns.

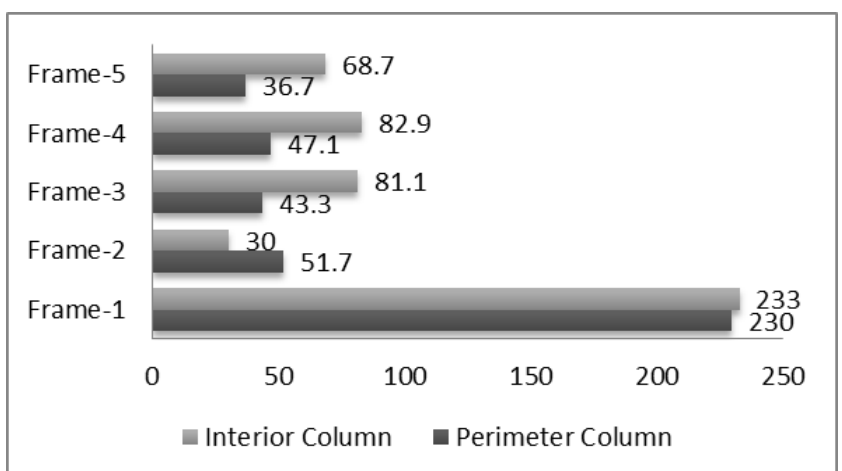

Fig. 2: Bending moment (kNm) in Ground Storey Columns.

Similarly, bending moments in top storey columns are shown in Fig. 3. The maximum value of bending Moment both in the case of interior and perimeter columns for top storey columns are seen in the case of Frame-1which is the frame with no shear wall which comes out to be 91.9 and $93.2 \mathrm{kNm}$ respectively whereas the minimum value for both are seen inthe cases of Frame- 2 and Frame- 4 where shear walls are placed at the inner core of the building symmetrically and shear wall symmetrically placed at exterior bays (centrally) which comes out to be $62.5,35.3$ and 27.9,35.3kNmrespectively. It is evident from figure that frame-2 and frame-4 show predominant reduction in bending moment.

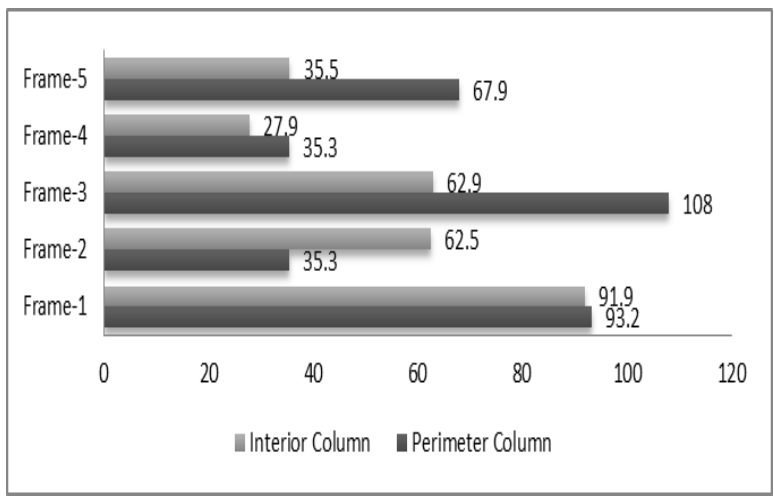

Fig. 3: Bending moment (kNm) in top Storey Columns

\subsubsection{Shear Force}

Shear force is a measure of lateral load borne by columns and shear walls. The maximum value of shear force both in the case of interior and perimeter columns for ground storey columns are seen in the case of Frame-1which is the frame with no shear wall comes out to be 106 and $104 \mathrm{kN}$ respectively whereas the minimum value for both are seen in the cases of Frame-2 and Frame-5 where shear walls are placed at the inner core of the building symmetrically and adjacently placed in exterior of the building which comes out to be $14.2,23.2 \mathrm{kN}$ and $26.2,14.1 \mathrm{kN}$ respectively. Figure 4 shows shear force in ground storey columns for all the frames. It is evident from the figure that frame- 2 and frame5 show significant reduction in shear force on ground floor. 


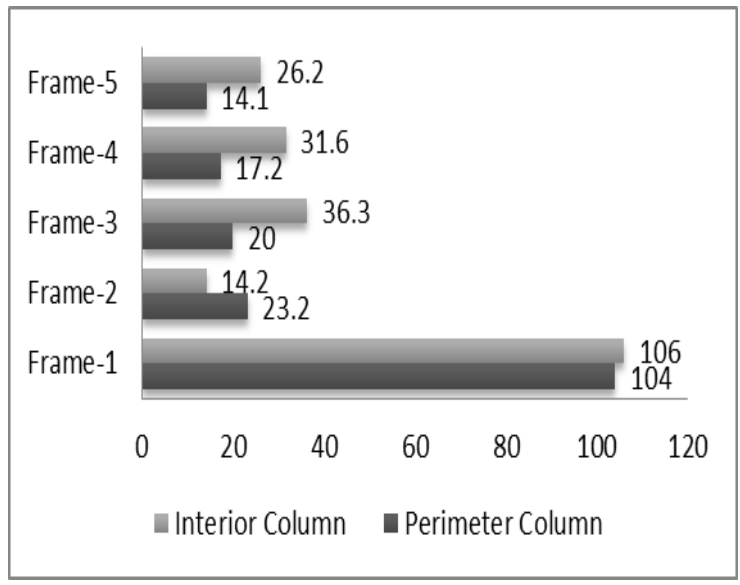

Fig. 4: Shear force (kN) in Ground Storey Columns.

Similarly, shear force in top storey columns is shown in Figure 5.The maximum value of Shear Force both in the case of interior and perimeter columns for top storey columns are seen in the case of Frame-1which is the frame with no shear wall comes out to be 106 and $104 \mathrm{kN}$ respectively whereas the minimum value for both are seen in the cases Frame- 2 and Frame-5 where shear walls are placed at the inner core of the building symmetrically and adjacently placed in exterior of the building which comes out to be $14.2,23.2 \mathrm{kN}$ and $26.2,14.1 \mathrm{kN}$ respectively.By looking at the results it can be inferred that frame- 2 and frame-5 shows maximum reduction in shear forces in top storey.

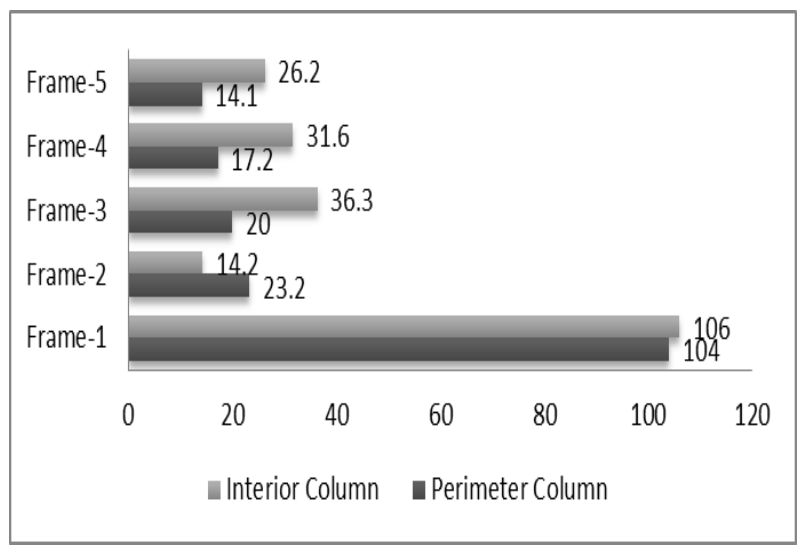

Fig. 5: Shear force (kN) in Top Storey Columns.

\subsubsection{Axial Force:}

The maximum value of axial force both in the case of interior and perimeter columns for ground storey columns are seen in the case of Frame-1which is the frame with no shear wall comes out to be 1066 and $797 \mathrm{kN}$ respectively whereas the minimum value for both are seen in the case of Frame-5 where shear walls are placed at the adjacently placed in exterior of the building which comes out to be 623 and $442 \mathrm{kN}$ respectively. By looking at Fig. 6, it is evident that the maximum reduction in axial force on ground floor is being experienced in case of frame-5.

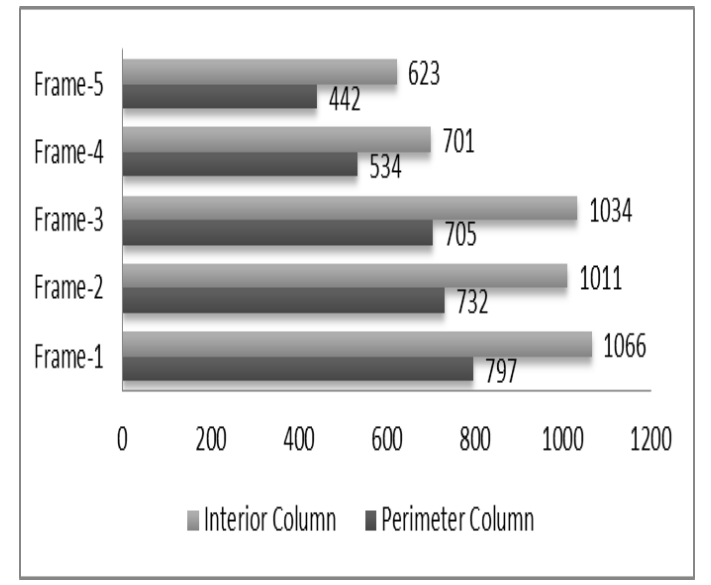

Fig. 6: Axial force (kN) in Ground Storey Columns.

The maximum value of shear force both in the case of interior and perimeter columns for top storey columns are seen in the case of Frame-1which is the frame with no shear wall comes out to be 152 and $119 \mathrm{kN}$ respectively whereas the minimum value for both are seen in the case of Frame-4 where shear walls are placed at the adjacently placed in exterior of the building which comes out to be 61.2 and 56.7 respectively.By looking at Fig. 7 , it is evident that the maximum reduction in axial force on top floor is being experienced in case of frame-4.

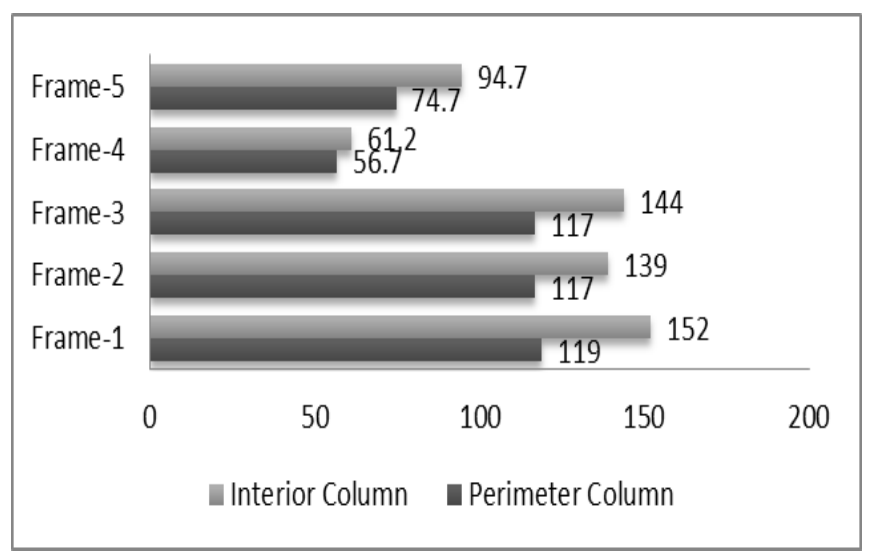

Fig. 7: Axial force (kN) in Top Storey Columns.

\subsubsection{Storey Drift}

Vales of storey drift in x-direction for all the frames and for each storey are given in Table 1 and plotted in Fig. 8. By analyzing these values, it can be concluded that frame- 2 in $\mathrm{x}$-direction and frame- 3 in $\mathrm{z}$-direction has maximum reduction in storey drift.

Table 1 Storey Drift in $x$-direction

\begin{tabular}{|l|l|l|l|l|l|}
\hline & \multicolumn{3}{|l|}{ Displacements (mm) in $x$-direction } & \\
\hline Storey & $\begin{array}{l}\text { Frame- } \\
\mathbf{1}\end{array}$ & $\begin{array}{l}\text { Frame- } \\
\mathbf{2}\end{array}$ & $\begin{array}{l}\text { Frame- } \\
\mathbf{3}\end{array}$ & $\begin{array}{l}\text { Frame- } \\
\mathbf{4}\end{array}$ & $\begin{array}{l}\text { Frame- } \\
\mathbf{5}\end{array}$ \\
\hline Fifth & 34.813 & 9.964 & 12.403 & 14.998 & 12.248 \\
\hline Fourth & 30.940 & 8.586 & 9.494 & 11.95 & 9.301 \\
\hline Third & 24.122 & 6.290 & 6.343 & 8.192 & 6.297 \\
\hline Second & 15.317 & 3.728 & 3.455 & 4.594 & 3.558 \\
\hline First & 6.040 & 1.406 & 1.182 & 1.507 & 1.344 \\
\hline
\end{tabular}




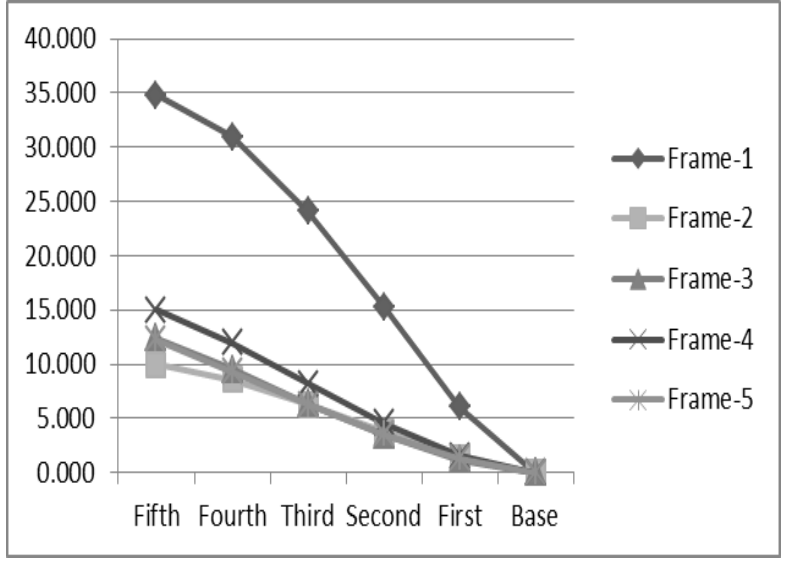

Fig. 8: Storey $\operatorname{drift}(\mathrm{mm})$ in $\mathrm{x}$-direction.

Table2 Storey drift in z-direction.

\begin{tabular}{|l|l|l|l|l|l|}
\hline & \multicolumn{5}{|l|}{ Displacement(mm) in Z direction } \\
\hline Storey & $\begin{array}{l}\text { Frame- } \\
\mathbf{1}\end{array}$ & $\begin{array}{l}\text { Frame- } \\
\mathbf{2}\end{array}$ & $\begin{array}{l}\text { Frame- } \\
\mathbf{3}\end{array}$ & $\begin{array}{l}\text { Frame- } \\
\mathbf{4}\end{array}$ & $\begin{array}{l}\text { Frame- } \\
\mathbf{5}\end{array}$ \\
\hline Fifth & 60.911 & 13.444 & 10.135 & 12.917 & 11.691 \\
\hline Fourth & 53.123 & 11.569 & 7.689 & 9.84 & 8.982 \\
\hline Third & 40.622 & 8.477 & 5.107 & 6.729 & 5.942 \\
\hline Second & 24.849 & 4.922 & 2.773 & 3.832 & 3.183 \\
\hline First & 8.944 & 1.129 & 0.961 & 1.621 & 1.039 \\
\hline
\end{tabular}

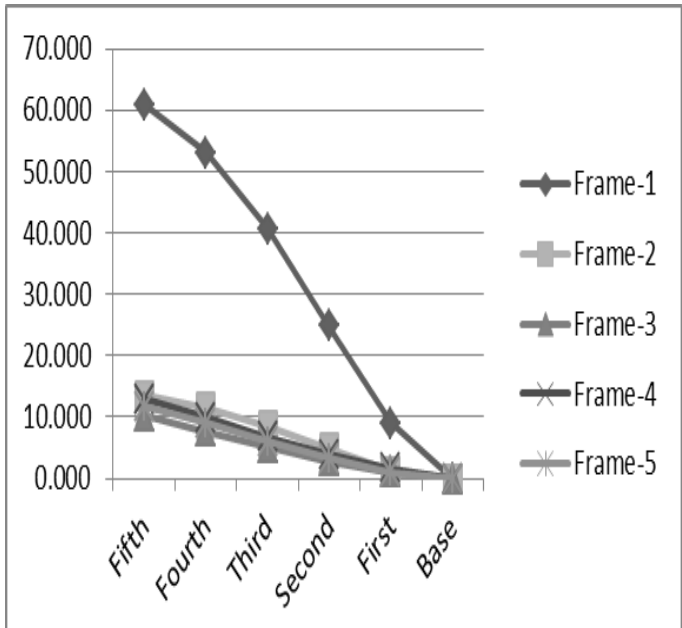

Fig. 9: Storey drift (mm) in z-direction.

The frame with shear walls at core and centrally placed at exterior bays showed significant reduction of order $29 \%$ to $83 \%$ in lateral displacement. The reduction in bending moments is approximately $70 \%$ to $85 \%$ for interior and perimeter columns respectively. Shear and axial forces in columns have reduced by $86 \%$ and $45 \%$ respectively.

\subsection{Curtailing best frames for economy}

\subsubsection{Curtailing top storey}

- Curtailing frame with shear wall at core 1) Curtailing Frame with shear walls at core -

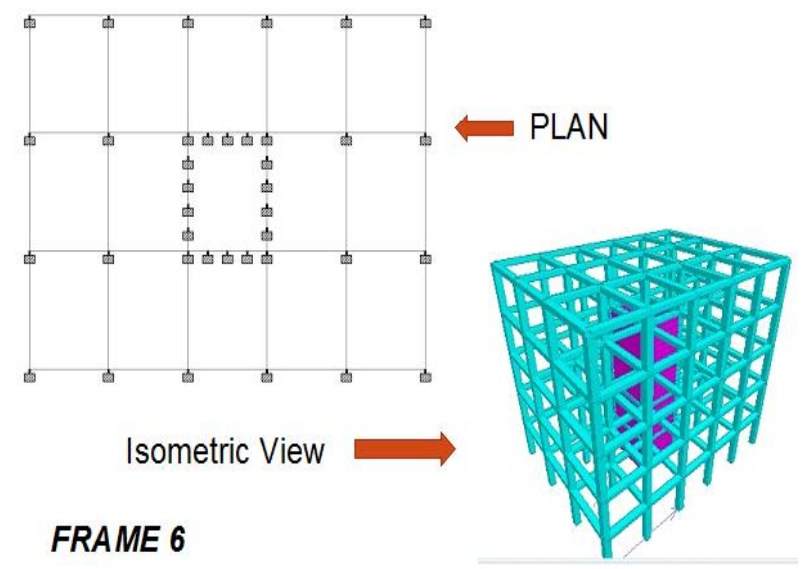

Fig. 10: Curtailment of top storey at core

- Curtailing frame with shear walls symmetrically placed at middle of exterior bay

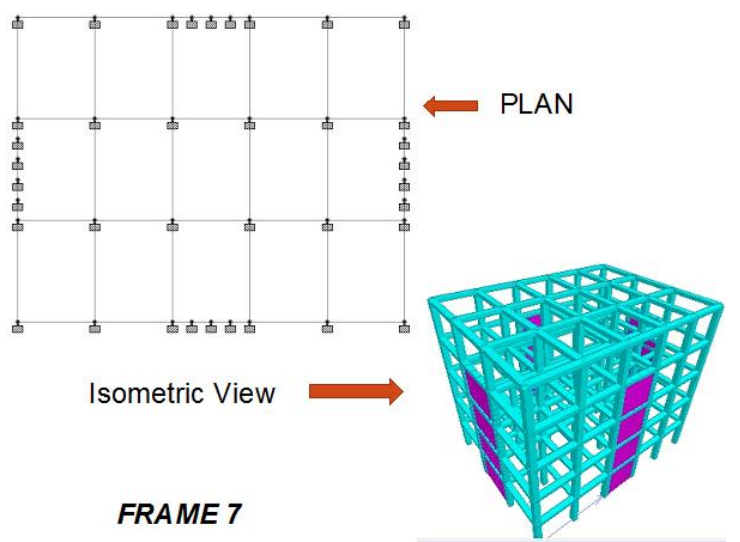

Fig. 11: Curtailment of top storey at middle of exterior bay

\subsubsection{Curtailing top two storeys}

- Curtailing frame with shear wall

at core 1) Curtailing Frame with shear walls at core -

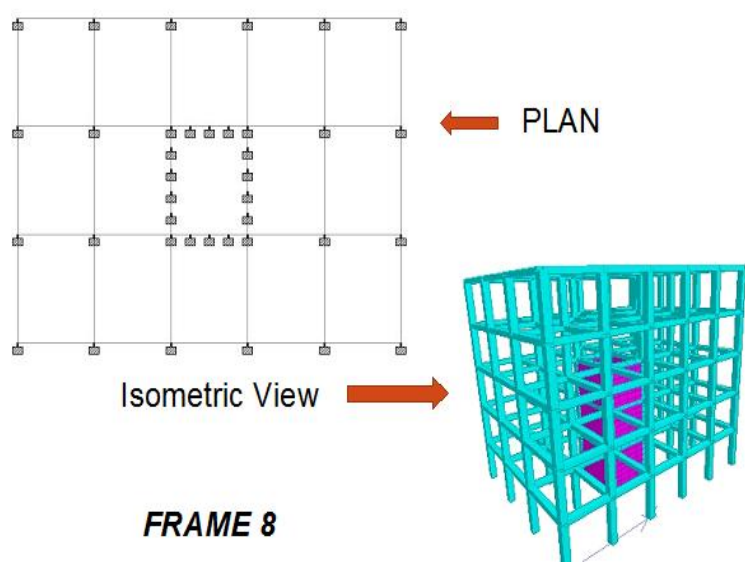

Fig.12: Curtailment of ground storey at core 
- Curtailing frame with shear walls symmetrically placed at middle of exterior bay

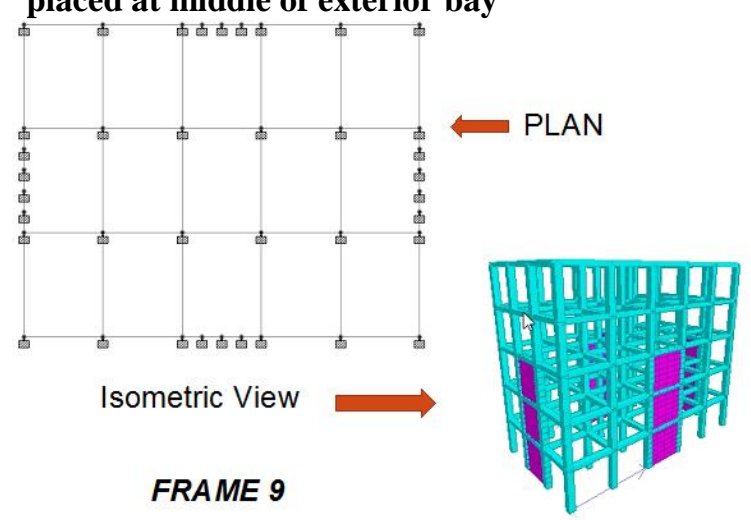

Fig. 13: Curtailment of top storey at middle of exterior bay

\section{RESULT}

\subsection{Maximum Bending Moment}

\subsubsection{Ground Storey}

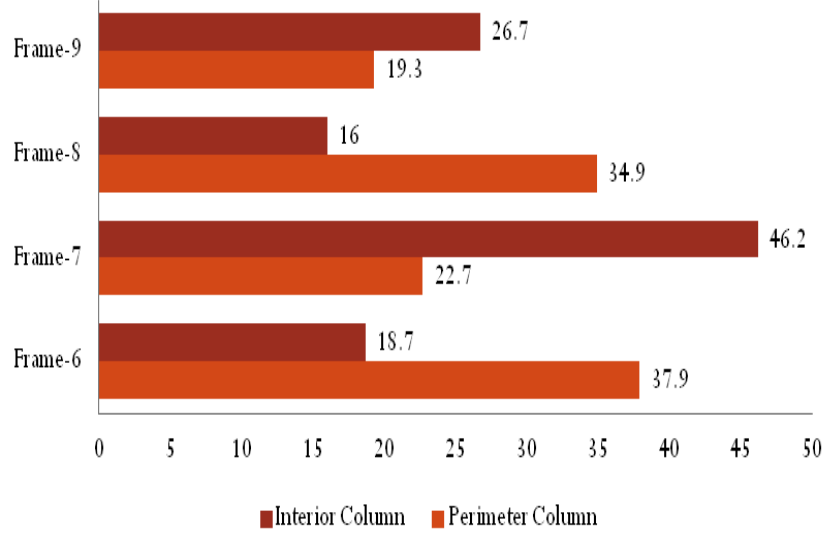

Fig. 14: Bending moment $(\mathrm{kNm})$ in Ground Storey Columns after cutailing

\subsubsection{Top Storey}

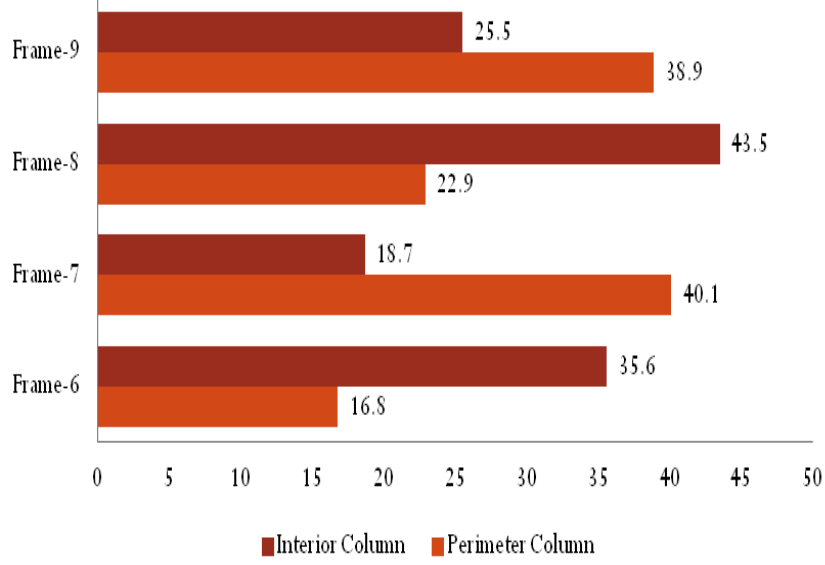

Fig. 15: Bending moment $(\mathrm{kNm})$ in top Storey Columns after curtailing.

\subsection{Shear Force}

\subsubsection{Ground Storey}

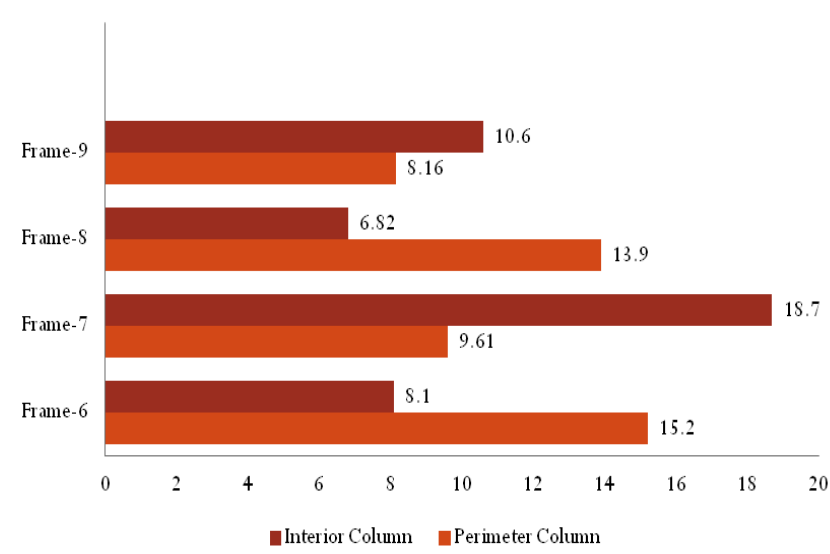

Fig. 16: Shear force $(\mathrm{kN})$ in Ground Storey Columns after curtailment.

\subsubsection{Top Storey}

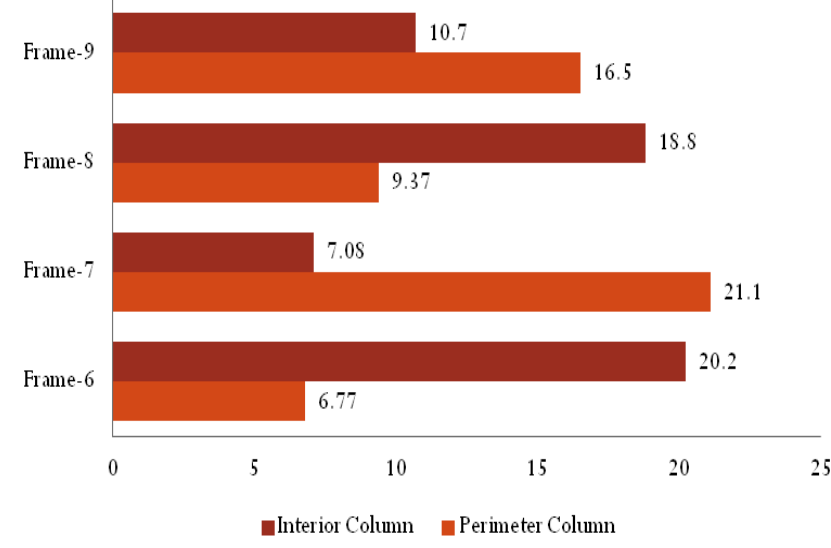

Fig. 17: Shear force $(\mathrm{kN})$ in Top Storey Columns after curtailment.

\subsection{Axial Force}

\subsubsection{Ground Storey}

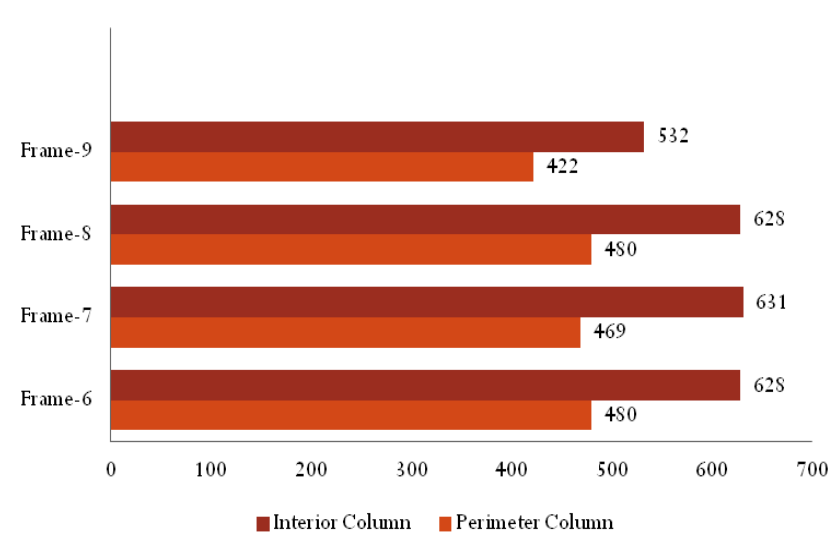

Fig. 18: Axial force $(\mathrm{kN})$ in Ground Storey Columns after curtailment. 


\subsubsection{Top Storey}

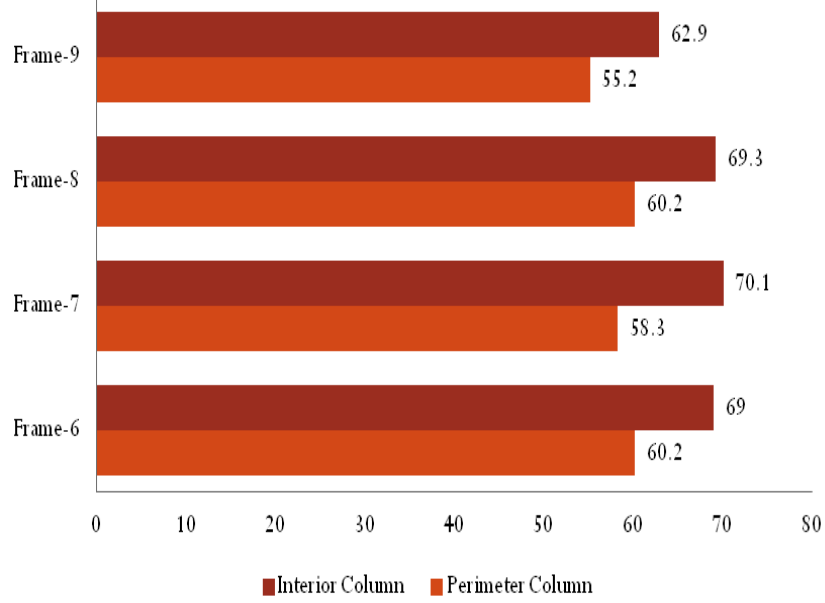

Fig. 19: Axial force $(\mathrm{kN})$ in Top Storey Columns after curtailment.

\subsection{Storey Drift}

\subsubsection{Displacement in X Direction}

Table 3 Storey drift in x-direction after curtailment

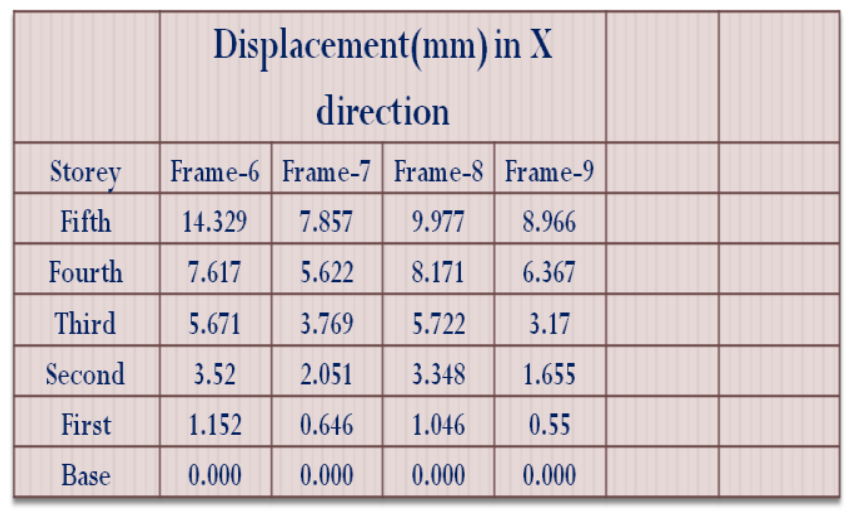

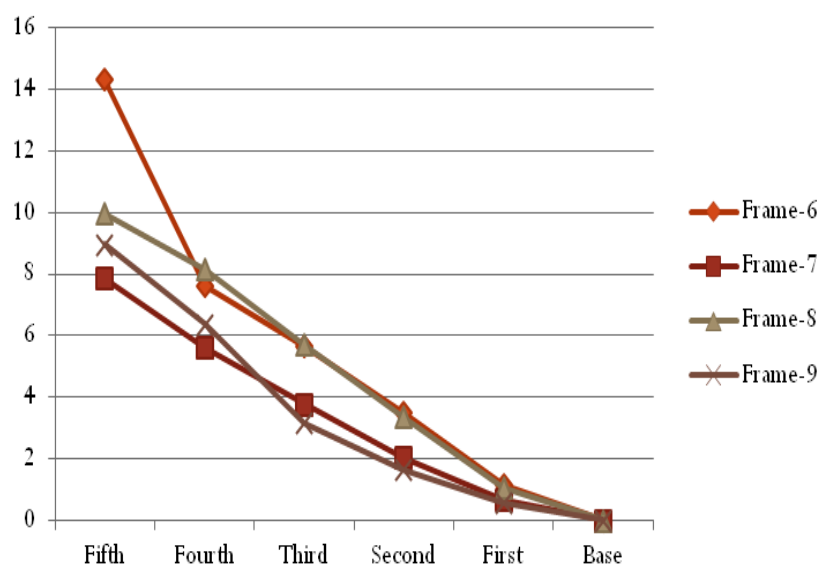

Fig. 20: Storey drift $(\mathrm{mm})$ in $\mathrm{x}$-direction after curtailment

\subsubsection{Displacement in Z Direction}

Table 4: Storey drift in z-direction after curtailment

\begin{tabular}{|c|c|c|c|c|c|l|}
\hline \multicolumn{7}{|c|}{ Displacement(mm) in Z direction } \\
\hline Storey & Frame-6 & Frame-7 & Frame-8 & Frame-9 & & \\
\hline Fifth & 14.329 & 9.468 & 16.989 & 14.821 & & \\
\hline Fourth & 11.981 & 5.508 & 13.595 & 10.184 & & \\
\hline Third & 8.761 & 3.613 & 9.407 & 4.811 & & \\
\hline Second & 5.222 & 2.004 & 5.229 & 2.572 & & \\
\hline First & 1.755 & 0.666 & 1.644 & 0.871 & & \\
\hline Base & 0.000 & 0.000 & 0.000 & 0.000 & & \\
\hline \hline
\end{tabular}

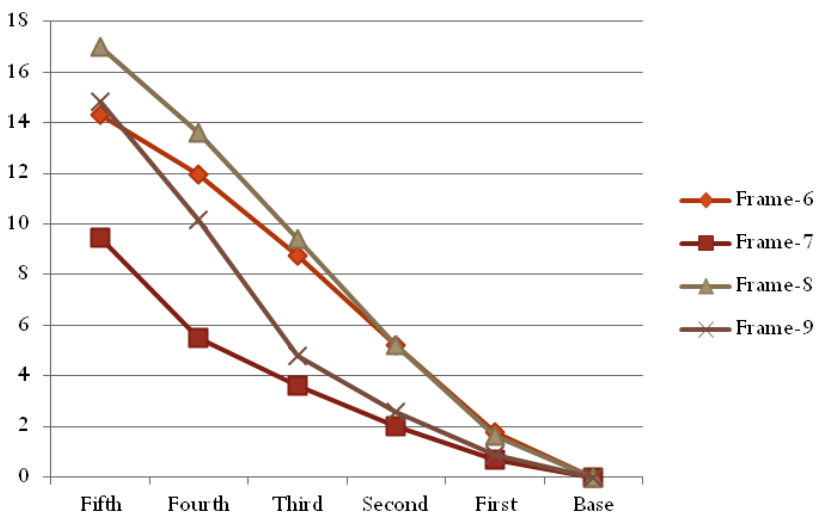

Fig. 21: Storey drift (mm) in z-direction after curtailment.

\section{CONCLUSIONS}

- $\quad$ Lateral load resisting capacity of the frame increases significantly in case of curtailment of shear wall , as is clear from the story displacements in $\mathrm{X}$ and $\mathrm{Z}$ directions.

- For Frame-7 (Curtailment of top story with shear walls at middle of exterior bays), lateral displacements are minimum in X-direction and merely $55 \%$ of the displacement of frame-6 (from $14.33 \mathrm{~mm}$ to $7.86 \mathrm{~mm}$ )

- The frame with shear walls at middle of exterior bays (Frame-7) performs best for earthquake in Zdirection. The reduction in response is as high as 44\% (16.99 $\mathrm{mm}$ to $9.47 \mathrm{~mm}$ ).

- Inter storey drift which is crucial for columns is also reduced appreciably with the curtailment of shear wall, minimum being for Frames-6 and Frame-7.

- As far as bending moments in ground floor columns are concerned, Frame- 9 and Frame- 8 shows significant reduction in the same as compared to those in Frame-7 and Frame-6. The reduction in B.M. is approximately 50 to $65 \%$ for perimeter and interior columns respectively

- Shear force in ground storey columns is also reduced by as high as $54 \%$ for Frame- 8 and Frame9. Hence, Shear force has reduced significantly with the curtailment of top two storeys. 
- Axial force in the columns during earthquake is reduced as much as $16 \%$ due to introduction of shear walls. Major reduction is seen for Frame-9.

- Similar trend in reduction of bending moments, shear forces and axial forces is seen in for top story columns. Frame- 8 and Frame- 9 are seen to perform better in this case.

- Shear walls are definitely good mechanism for lateral loads mitigation, but the placement of shear walls should be made judiciously. In order to make the building economically feasible, curtailment should be done up to a certain height from the top. In the present case, the Frame-9 (curtailment of top two storeys with shear walls symmetrically placed at middle of exterior bays) is seen to perform better in major number of cases.

\section{ACKNOWLEDGEMENTS}

We would like to pay our sincere gratitude to our project guide $\mathrm{m} / \mathrm{s}$ Poonam Dhiman and faculty of civil engineering Dr. Anil Dhiman for their whole hearted support and motivation. Without their proper guiding this paper would not be possible.

\section{REFERENCES}

[1] Ansul Sud, Raghav Singh Shekhawat, Poonam Dhiman (March 2014) “ Best Placement Of Shear Walls In A RCC Space Frame Based On Seismic Response" International Journal of Engineering Research and Applications (IJERA) ,Special Issue Archive AET Mar2014

[2] IS: 875(Part 1) - 1987 (Reaffirmed 2003), Code of Practice for Design Loads (Other than Earthquake) For Buildings and Structures (Second Revision).

[3] IS: 875(Part 2) - 1987 (Reaffirmed 2003), Code of Practice for Design Loads (Other than Earthquake) For Buildings and Structures (Second Revision).

[4] IS: 456-2000(Reaffirmed 2005), Indian Standard Code of Practice for Plain and Reinforced Concrete (Fourth Revision), Bureau of Indian Standards, New Delhi.

[5] IS: 1893-2002, Indian Standard Recommendations for Earthquake Resistant Design of Structures, Bureau of Indian Standards, New Delhi.

[6] C K Wang, Intermediate structures, McGraw Hills, 2004.

[7] Aggarwal and Shrikhande, Earthquake resistant design of structures, PHI Learning Limited, 2006. 